\title{
建物ポイントデータの床面積補正を通じた 民生部門エネルギー消費量の推計
}

\author{
石河 正寛 1 -松橋 啓介 2 - 有賀 敏典2 \\ 1非会員 国立環境研究所 社会環境システム研究センター（テ305-8506 茨城県つくば市小野川16-2） \\ E-mail:ishikawa.masahiro@nies.go.jp \\ 2正会員 国立環境研究所 社会環境システム研究センター（テ305-8506 茨城県つくば市小野川16-2）
}

\begin{abstract}
建物ポイントデータを用いた民生家庭・業務部門のエネルギー消費量の推計手法を改善し, 地球温暖化 対策地方公共団体実行計画の策定に資するデータを提案する. 床面積に関する統計值を組み合わせて集合 住宅の共用部の割合を示し，都道府県別および市別に戸建住宅，集合住宅，非住宅の用途の別に基準とな る床面積を求めた。 これを対応する用途別に集計した建物ポイントデータの床面積で除し, 補正係数を算 出した．補正した床面積に空家率も考慮して原単位を乗じることでエネルギー消費量を推計し，これを都 道府県別および政令市別の各種エネルギ一統計值と比較することで, 従来手法よりも高い再現性が得られ ることを確認した．この方法による市のエネルギー消費量およびその分布を用いることで，街区等でのエ ネルギー対策による削減量の見積が容易になる.
\end{abstract}

Key Words : building point data, total floor space, vacant house, energy consumption

\section{1. はじめに}

我が国の自治体は，地球温暖化対策の推進に関する法 律に基づく地方公共団体実行計画（以下，実行計画）の 策定・実施を求められている. 実行計画の策定には，区 域の温室効果ガス排出量の目標設定が必要であり,この 目標を設定するためには，区域の現況排出量を把握する とともに，地方公共団体等の対策・施策による温室効果 ガス排出量の削減可能量の見積を行う必要がある. また, 地球温暖化対策に係る中長期ロードマップ1に盛り込ま れた「地域づくり」に関する施策のうち, 地区・街区単 位のエネルギー対策の更なる具体化を図るためには，区 域内のエネルギ一消費について, 地区・街区や建物の特 性を踏まえた, より詳細な空間スケールで推計を行うこ とが必要である.

現在，国が示寸実行計画策定に係る参考図書には，環 境省の手引き2) と国交省のハンドブック33が存在する. 環 境省の手引きでは, 区域におけるすべての経済活動に由 来するエネルギー消費量を, 都道府県や市町村の統計か ら推計する方法が示されている. しかし，この方法では 街区・地区や建物の特性を反映した区域内のエネルギー 消費分布を知ることができない，一方，国交省のハンド ブックでは，都市計画基礎調査を活用することで，区域 内のエネルギー消費分布を把握可能とする方法が示され
ている.ただし，都市計画基礎調査を行って建物属性を はじめとする詳細な特性を調査している自治体は市全体 の3割しかなく4), 多くの自治体では地区・街区単位の工 ネルギー対策を検討することが困難な状況にある.

こうした中，ゼンリンが近年公開した建物ポイントデ 一タ5)を都市計画基礎調査の代わりに利用することで, 国内すべての自治体が区域の現況排出量の把握ならびに まちづくりと連動した地区・街区単位のエネルギー対 策・施策を検討することの可能な環境が整いつつある. 建物ポイントデータは, ゼンリンの住宅地図をべースに 作成された，全国約 3,800 万棟の建物一軒ごとの情報を 収録したデータであり, 建物用途や建築面積, 延床面積

(以下, 床面積), 階数, 部屋数などが属性情報として 付されている. 実際に建物ポイントデータを利用したエ ネルギー分析の先行例として, 日建総研 6 による成果が 存在する.

日建総研の検討では，建物ポイントデータに収録され ている床面積にエネルギー消費原単位を乗じてエネルギ 一消費量を推計し，データベースとして提供している. しかし, 建物ポイントデータに収録されている床面積は, 住宅地図上の建物外形面積に階数を乗じて求めた值であ る. この方法で推定された床面積は, 屋根伏せの形状を 建物の外形線の基準としていることや，建物内のピロテ イやアトリウム等の中空部分についての図形情報がない 
ことなどにより，課税面積などの法令上の床面積よりも 過大になること召が指摘されている．また，エネルギー 消費量の推計においては空家分を除外して推計すること が適切と考えられるが，建物ポイントデータには空家に 関する情報が十分でないため, 日建総研の推計において も空家を考慮できていないという課題がある．地区・街 区単位のエネルギー対策・施策は，エネルギー需給のマ ッチングを通じて効果を得るものであり, 過大に推計さ れたエネルギー消費量に基づく削減可能量の見積では, 実際に期待通りの施策効果を得ることが困難である.

そこで本研究は, 地球温暖化刘策地方公共団体実行計 画のエネルギー（民生家庭・民生業務）の策定に役立つ 基盤的データの整備を目指して, 建物ポイントデータの 床面積補正係数を都道府県別に算出し, 補正した床面積 に空家を考慮して推計したエネルギ一消費量について, 各種エネルギー統計の都道府県および政令市の值に対す る再現性を確かめるとともに, この方法を用いて市の工 ネルギー消費量およびその分布を推計する方法を提案す ることを目的とする.

\section{2. 方法}

建物ポイントデータの床面積補正係数の算出と空家の 考慮は, 図-1に示寸方法で行う。また, この補正した建 物ポイントデータの集計值に原単位を乗じてエネルギー 消費量を推計し, 各種エネルギ一統計との比較を行うこ とで再現性を確かめる.さらに, この方法を適用して, 市のエネルギー消費量を求め, 既存手法との比較を行う とともに，エネルギー消費分布を示す．以下，(1)床面
積の補正，(2)空家の考慮，(3)エネルギー消費推計の方 法について詳細を述べる.

\section{（1）床面積の補正}

床面積の補正は, 都道府県別建物用途別に行うことを 基本とする．まず，各種統計資料を用いて，都道府県別 建物用途別の床面積值を作成し，この床面積值と整合す るように建物ポイントデータの床面積を補正する.

都道府県別建物用途別の床面積値は, 固定資産価格概 要書8), 公共施設状況調9および国有財産一件別情報10)

（以下，固定資産概要書等）から都道府県別の住宅・非 住宅別床面積を収集し，住宅・非住宅のそれぞれについ て次の方法で建物用途分類を細分化する.

\section{a) 住宅}

固定資産価格概要書等は, 全数調査であるため, 他の 統計に比較して, 床面積の総量の信頼性は高いと考えら れる. 一方，非木造住宅については戸建住宅か集合住宅 かの建て方別の分類がないため, エネルギー消費原単位 が異なる建て方別の床面積を求めるためには不十分であ る. そこで，固定資産概要書等の住宅床面積と住宅・土 地統計調査の建て方別床面積を組み合わせて, 住宅の都 道府県別建て方別床面積值を作成する. なお，住宅・土 地統計調査の都道府県別建て方別床面積については, 一 戸建を戸建住宅，長屋建・共同住宅・その他の3つを集 合住宅の2区分に対応させ，それぞれの住宅総数に1住宅 あたり床面積を乗じて算出する.

固定資産概要書等における住宅床面積には集合住宅の 共用部が含まれる一方で, 住宅・土地統計調査における 集合住宅の床面積には共用部が含まれない，そこで，固 定資産概要書等における都道府県別住宅床面積を被説明

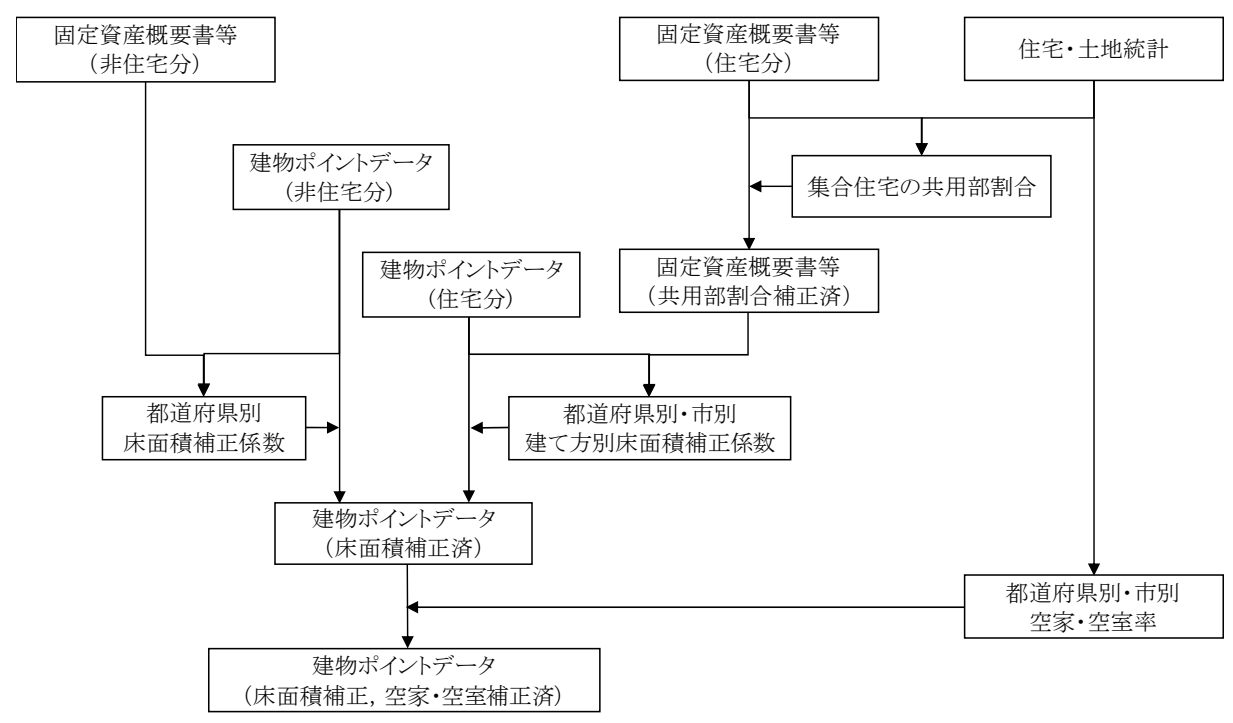

図-1 建物ポイントデータの床面積補正および空家考慮の方法 
変数, 住宅・土地統計調査における都道府県別の建て方 別床面積を説明変数として，切片ゼロを仮定した重回州 分析を行い，住宅・土地統計調查の建て方別床面積に共 用部を加味するための係数を算出する. 固定資産概要書 等の床面積と住宅・土地統計調査の床面積の相違点が集 合住宅共用部の有無だけであるならば，住宅・土地統計 調查の建て方別床面積を説明変数とした重回帰分析によ り得られる偏回帰係数は，戸建で1，集合で1以上となる。 この集合の偏回帰係数が住宅・土地統計調查の集合住宅 床面積に共用部を加味するための係数となる.

住宅・土地統計調査の都道府県別建て方別床面積に, 重回帰分析で得られる偏回帰係数をそれぞれ乗じた值を, 住宅の建て方別床面積值とする．なお，市についても都 道府県と同様の方法で市別の建て方別床面積值を作成可 能である. しかし, 固定資産概要書等の床面積は住宅・ 非住宅別の市区町村別值が公表されていないため, 今回 の試行では, 住宅・土地統計調查の市別建て方別床面積 に, 都道府県単位の重回帰分析で得られた偏回帰係数を 乗じた值を住宅の市別建て方別床面積值とすることで, 市の地域特性を生かした床面積補正係数を求める.

\section{b) 非住宅}

非住宅床面積については, 法人建物調査を用いた建物 用途分類の細分化を試行した. しかし，今回の試行では 建物ポイントデータと整合する建物用途分類を確立する ことができなかった．この理由として，建物ポイントデ 一タにおける非住宅用途の分類が業種別のものであるこ とが挙げられる. そのため, 非住宅床面積については, 建物用途別ではなく, 全用途一括で床面積補正する.

床面積補正における建物ポイントデータと固定資産概 要書等の建物用途分類の対応関係は表-1の通りである.

\section{(2) 空家の考慮}

住宅・土地統計調查から，建て方別空家率を取得する ことができる. 市部については，集合住宅も含めて十分 な調査サンプル数が得られる. そこで, 住宅について, 住宅・土地統計調査から都道府県別あるいは市別（以下， 県市別）の建て方別空家率を計算し，これを県市別建て 方別床面積に乗じることで，床面積補正に加えて空家を 考慮した建物ポイントデータに基づく建て方別の床面積 を求める. なお, 空家率は, 居住世帯のない住宅数を住 宅総数で除して算出する.

また，市内のエネルギー消費量の分布を図示寸るため に, 建物ポイントデータ単位での空家の考慮を試みる. 建物ポイントデータには空家を判定するための情報は収 録されていないものの, 建物ごとの表札名・事業所名を カウントした「総部屋数」が収録されている. そこで, 住宅・非住宅の「総部屋数」をそれぞれ「住宅数」「事 業所数」と読み替え, 次の方法で都道府県別に空家・空 ビルをランダムに選定する.

まず住宅について，住宅・土地統計調査から県市別の 建て方別空家率を算出し，これを建物ポイントデータの 県市別総部屋数に乗じて, 建物ポイントデータにおける 県市別の建て方別空家数を算出する. 次に, 算出した県 市別の建て方別空家数を満たすよう, 建物ポイントデー タの戸建住宅と集合住宅それぞれについて，県市別に建 物単位の無作為抽出を行い, 空家とみなす住宅を選定す る. なお，今回試行する空家の選定法は，戸建・集合と も建物1棟単位で空家化していると仮定したものである が，集合住宅については1室単位で空室選定を行う方法 が合理的との指摘もある. しかしながら室単位の空室発 生メカニズムについて妥当な方法を設定することができ なかったことから，ここでは1棟単位の空室化を仮定し ていることに留意する必要がある.

表-1 床面積補正およびエネルギー消費推計における建物用途分類の対応関係

\begin{tabular}{|c|c|c|c|c|}
\hline \multirow{2}{*}{ 部門 } & \multirow{2}{*}{ 【建物ポイントデータ 】 } & \multicolumn{2}{|c|}{ 床面積補正 } & \multirow{2}{*}{$\begin{array}{l}\text { エネルギー } \\
\text { 消費推計 } \\
\end{array}$} \\
\hline & & 民間施設 & 公共施設 & \\
\hline \multirow[b]{2}{*}{$\begin{array}{l}\text { 民生 } \\
\text { 家庭 }\end{array}$} & 個人の家屋, 事業所兼住宅 & \multirow{2}{*}{$\begin{array}{c}\text { 【固定資産価格概要調書 }{ }^{* 2} \text { 】 } \\
\text { 専用住宅, } \\
\text { 共同住宅·宿舎, } \\
\text { 併用住宅(住宅部分), } \\
\text { 農家住宅, } \\
\text { 住宅·アパート }\end{array}$} & \multirow{2}{*}{$\begin{array}{c}\text { 【公共施設状況調 }{ }^{* 3} \text { 】 } \\
\text { 公営住宅 } \\
\text { 【国有財産一件別情報 }{ }^{* 4} \text { 】 } \\
\text { 宿舎 }\end{array}$} & 戸建住宅 \\
\hline & $\begin{array}{l}\text { マンション, アパート, 団地, } \\
\text { 寮・社宅, 住宅系建物 }\end{array}$ & & & 集合住宅 \\
\hline \multirow{6}{*}{$\begin{array}{l}\text { 民生 } \\
\text { 業務 }\end{array}$} & $\begin{array}{l}\text { 金融·保険, 不動産, 専門職, } \\
\text { 宅配·引越·郵便, 協同組合, } \\
\text { インフラ, 運輸, 建設·設備, } \\
\text { 自動車関連, 一般業, } \\
\text { オフィス複合系建物, オフィス系建物 }\end{array}$ & \multirow{6}{*}{$\begin{array}{c}\text { 【固定資産価格概要調書 }{ }^{* 2} \text { 】 } \\
\text { 併用住宅(非住宅分), } \\
\text { 旅館・料亭・ホテル, } \\
\text { 事務所・店舗, } \\
\text { 劇場・病院, } \\
\text { 公衆浴場, } \\
\text { 工場・倉庫, } \\
\text { 事務所・店舗・百貨店・銀行, } \\
\text { 病院・ホテル, } \\
\text { 工場・倉庫・市場, } \\
\text { その他 }\end{array}$} & \multirow[t]{6}{*}{$\begin{array}{c}\text { 【公共施設状況調 }{ }^{* 3} \text { 】 } \\
\text { 公営住宅以外の公有財産建物 } \\
\\
\text { 【国有財産一件別情報 }{ }^{* 4} \text { 】 } \\
\text { 宿舎以外の国有財産建物 }\end{array}$} & 事務所 \\
\hline & $\begin{array}{l}\text { 飲食, 物販, サービス, 量販店 } \\
\text { 商業複合系建物, 商業系建物 }\end{array}$ & & & 商業施設 \\
\hline & 医療・福祉 & & & 医療施設 \\
\hline & ホテル・旅館 & & & 宿泊施設 \\
\hline & スポーツ施設, 娛楽, 公共, 宗教関連 & & & 文化施設 \\
\hline & 教育 & & & 教育施設 \\
\hline 対象外 & その他 & $\begin{array}{c}\text { 【固定資産価格概要調書 } \\
\text { 土蔵, 附属家 } \\
\end{array}$ & & \\
\hline
\end{tabular}


非住宅については，空室率として住宅・土地統計調査 における集合住宅の空家率を適用し，住宅の空家選定方 法と同じ要領で空ビルとみなす建物を選定する. 非住宅 の空室率には法人建物調査の值を適用することも検討し たが，(1)サンプル数の少ない都道府県で值の誤差が大き いと考えられたこと，(2)市場ニーズに応じた地域間の差 の傾向が見られなかったこと, が課題として挙げられた. そのため, 今回の試行では, 室単位の空室発生メカニズ ムを持つという点で類似する集合住宅の空家率を適用し た. なお，非住宅についてもフロア・テナント単位の空 室選定が合理的であると考えられるが，集合住宅と同様， そのメカニズムが不明なことから，建物単位で空ビル化 しているものと仮定して簡易的に計算する.

\section{(3) エネルギ一消費量の推計}

以上の方法で作成した建物ポイントデータの床面積補 正および空家考慮の有無別床面積を用いて，原単位法に よるエネルギー消費量推計を行う.

エネルギー消費原単位（以下，原単位）は，住宅は平 成24年度エネルギー消費状況調査 ${ }^{11}$ に記載されている気 候区分別・建て方別・エネルギー源別の世帯あたりエネ ルギー消費量をグラフから読み取り，住宅・土地統計調 査の1住宅当たり床面積で除して, 床面積あたりの原単 位を作成する. 非住宅の原単位は, 非住宅建築物の環境 関連データベース ${ }^{12}$ （以下，DECC）の気候区分別・建 物用途別・エネルギー源別の床面積当たりの值を使用す る.なお，DECCは8つの地方区分ごとに24の建物用途分 類項目を設けているものの, 未調査やサンプル数の少な

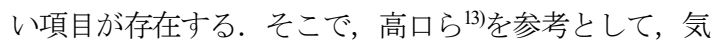
候区分のうち中部と近畿, 中国・四国と九州を統合する. また，建物用途のうち事務所を業務施設，デパート・ スーパーを商業施設, ホテル・旅館を宿泊施設, 病院を 医療施設，高校を教育施設，展示施設を文化施設の代表 值として選定する．建物ポイントデータと原単位の建物 用途分類の対応関係を表-1に示す．なお，建物ポイント データのうちインフラ, 運輸, 建設・設備, 自動車関連, 一般業の 5 業種については, 産業部門に相当すると判断 して, エネルギー消費量の推計からは除外する.

\section{3. 床面積補正とエネルギ一消費量推計の結果}

\section{(1) 床面積補正係数}

集合住宅の共用部を加味する係数を求める重回帰分析 を行った結果, 戸建は0.941, 集合は1.109の偏回帰係数 を得た（補正 $R^{2} ： 0.977 ）$. 戸建の偏回帰係数が1を若干 下回った理由として, 住宅・土地統計調査が標本調査で あることのゆらぎ, 都道府県ごとのレンタブル比の違い,
併用住宅の非住宅部分の床面積が固定資産概要書等には 含まれない一方で住宅・土地統計調査には含まれること の影響が考えられる. 一方, 集合の偏回帰係数から求め られるレンタブル比は 0.901 となった. 一般的な賃貸マ ンションのレンタブル比は $90 \%$ 前後と言われており ${ }^{14)}$, 前述した誤差の影響を考慮しても妥当な值と判断した.

住宅・土地統計調查の都道府県別建て方別床面積にこ れらの偏回帰係数を乗じた值を住宅の建て方別床面積と し，これを表-1に示した用途別に集計した建物ポイント データの床面積で除して, 補正係数を求めた. 表-2に戸 建住宅，集合住宅，非住宅の都道府県別床面積補正係数

表-2 建物ポイントデータの床面積補正係数

\begin{tabular}{|c|c|c|c|}
\hline \multirow{2}{*}{ 都道府県 } & \multicolumn{2}{|c|}{ 住宅 } & \multirow{2}{*}{ 非住宅 } \\
\hline & 戸建 & 集合 & \\
\hline 北海道 & 0.670 & 0.905 & 0.714 \\
\hline 青森 & 0.631 & 0.904 & 0.686 \\
\hline 岩手 & 0.545 & 0.874 & 0.667 \\
\hline 宮城 & 0.613 & 0.785 & 0.654 \\
\hline 秋田 & 0.585 & 0.816 & 0.608 \\
\hline 山形 & 0.599 & 0.709 & 0.587 \\
\hline 福島 & 0.545 & 0.783 & 0.678 \\
\hline 茨城 & 0.599 & 0.851 & 0.717 \\
\hline 栃木 & 0.603 & 0.789 & 0.756 \\
\hline 群馬 & 0.634 & 0.894 & 0.697 \\
\hline 埼玉 & 0.772 & 0.810 & 0.731 \\
\hline 千葉 & 0.715 & 0.843 & 0.709 \\
\hline 東京 & 0.818 & 0.825 & 0.684 \\
\hline 神奈川 & 0.773 & 0.830 & 0.824 \\
\hline 新潟 & 0.657 & 0.839 & 0.702 \\
\hline 富山 & 0.659 & 0.747 & 0.708 \\
\hline 石川 & 0.674 & 0.769 & 0.702 \\
\hline 福井 & 0.601 & 0.773 & 0.681 \\
\hline 山梨 & 0.660 & 0.850 & 0.720 \\
\hline 長野 & 0.589 & 0.856 & 0.717 \\
\hline 岐阜 & 0.657 & 0.841 & 0.715 \\
\hline 静岡 & 0.671 & 0.841 & 0.738 \\
\hline 愛知 & 0.694 & 0.806 & 0.801 \\
\hline 三重 & 0.630 & 0.811 & 0.815 \\
\hline 滋賀 & 0.709 & 0.790 & 0.786 \\
\hline 京都 & 0.692 & 0.797 & 0.736 \\
\hline 大阪 & 0.725 & 0.835 & 0.783 \\
\hline 兵庫 & 0.710 & 0.809 & 0.781 \\
\hline 奈良 & 0.686 & 0.921 & 0.680 \\
\hline 和歌山 & 0.643 & 0.892 & 0.776 \\
\hline 鳥取 & 0.595 & 1.150 & 0.653 \\
\hline 島根 & 0.572 & 0.970 & 0.634 \\
\hline 岡山 & 0.592 & 0.856 & 0.767 \\
\hline 広島 & 0.608 & 0.806 & 0.765 \\
\hline 山口 & 0.558 & 0.843 & 0.808 \\
\hline 徳島 & 0.639 & 0.928 & 0.845 \\
\hline 香川 & 0.576 & 0.859 & 0.718 \\
\hline 愛媛 & 0.603 & 0.839 & 0.794 \\
\hline 高知 & 0.613 & 0.870 & 0.723 \\
\hline 福岡 & 0.597 & 0.772 & 0.710 \\
\hline 佐賀 & 0.539 & 0.812 & 0.687 \\
\hline 長崎 & 0.571 & 0.884 & 0.767 \\
\hline 熊本 & 0.530 & 0.837 & 0.729 \\
\hline 大分 & 0.552 & 0.809 & 0.729 \\
\hline 宮崎 & 0.511 & 0.790 & 0.691 \\
\hline 鹿児島 & 0.476 & 0.858 & 0.680 \\
\hline 沖縄 & 0.473 & 0.756 & 0.627 \\
\hline 全国平均 & 0.647 & 0.827 & 0.731 \\
\hline
\end{tabular}


を示す. 全国平均の值では，3つの建物用途の中で戸建 住宅が 0.647 と最も低い值となった。 戸建住宅は，軒や 庇が多く, 1階部分が2階部分よりも大きい下屋型の建物 も多い，一方，集合住宅や非住宅ではこうした特徵を持 つ建物は少なく, ブロック状の建物が多数を占める. 建 物形状の違いが結果に反映されていると考えられた。

表-2の補正係数をそれぞれ建物ポイントデータの床面 積に乗じることで, 統計上の床面積と整合する建物ポイ ントデータの床面積を求めることができる.

\section{a) 都道府県別の床面積補正係数の違い}

表-2の補正係数は, 戸建住宅については, 東京や大阪 など都市化度合いの高い都道府県で高い值となり，その 他の地方圈では低い值となっている．都市化度合いの高 い地域では, 軒や庇の張り出しが小さく, 総二階建ての 建物が占める割合が多くなることから, 建物ポイントデ ータの床面積をあまり縮小せずに済むと解釈できる，一 方，地方圈に関しては，全般的に下屋型の建物が多いこ とに加え, 北日本では風除室の存在, 南日本では夏の日 射を遮るための深い軒の存在のため, 建物ポイントデー 夕の床面積を大きく縮小寸る必要があると考えられた.

一方で, 集合住宅と非住宅については, 都道府県間の 值の差に明確な地域性を見出すことができなかった。こ の理由として, 建物様式の地域差が戸建住宅よりも小さ い可能性がある. また, 建物ポイントデータの階数不詳 建物数の割合の影響が考えられた，たとえば，鳥取県の 集合住宅の補正係数は特異的に大きく，1を超過してい る. そこで, 集合住宅の階数不詳建物数を調べた結果, 鳥取県の集合住宅の全建物数のうち, 約 $76 \%$ にのぼるこ
とが分かった. 集合住宅は一般的に二階建以上の建物で あると考えられるが，建物ポイントデータでは階数不詳 建物を二階建と見なして床面積を計算しているため, 階 数不詳建物数が多い県においては, 一部に特異的な值が 現れる場合があることに留意する必要がある.ただし， 鳥取県では集合住宅の建物数が少なく, 戸建住宅を含む 床面積全体に与える影響は大きくないと考えられる.

\section{b) 市区町村別の床面積補正係数}

住宅・土地統計調查では，小規模自治体における集合 住宅のサンプル数が少ないことから, 町村部について信 頼性のある值を求めることができない，また，固定資産 価格概要調書等には, 市区町村の值がない, そのため, 市についてのみ, 住宅・土地統計調査の市別住宅建て方 別床面積に偏回帰係数をそれぞれ乗じることで, 市別の 住宅建て方別床面積值を求め, これを用途別に集計した 建物ポイントデータの床面積で除して, 市別の床面積の 補正係数を建て方別に求める方法も適用した. なお, 非 住宅については, 市別に把握できる情報がないため, 都 道府県別の床面積補正係数を用いることとなる.

\section{（2）エネルギ一消費量推計の再現性}

建物ポイントデータの集計値と床面積補正係数および 空家率，エネルギー消費原単位を用いて，住宅と非住宅 の別にエネルギー消費量を求めた．推計したエネルギー 消費量について，資源エネルギー庁の都道府県別エネル ギー消費統計15) と比較し, 補正の有無による再現性の違 いをみる．住宅・非住宅別の補正有無のケース別による エネルギー消費量の比較結果を図-2 に示寸，なお，都

住宅

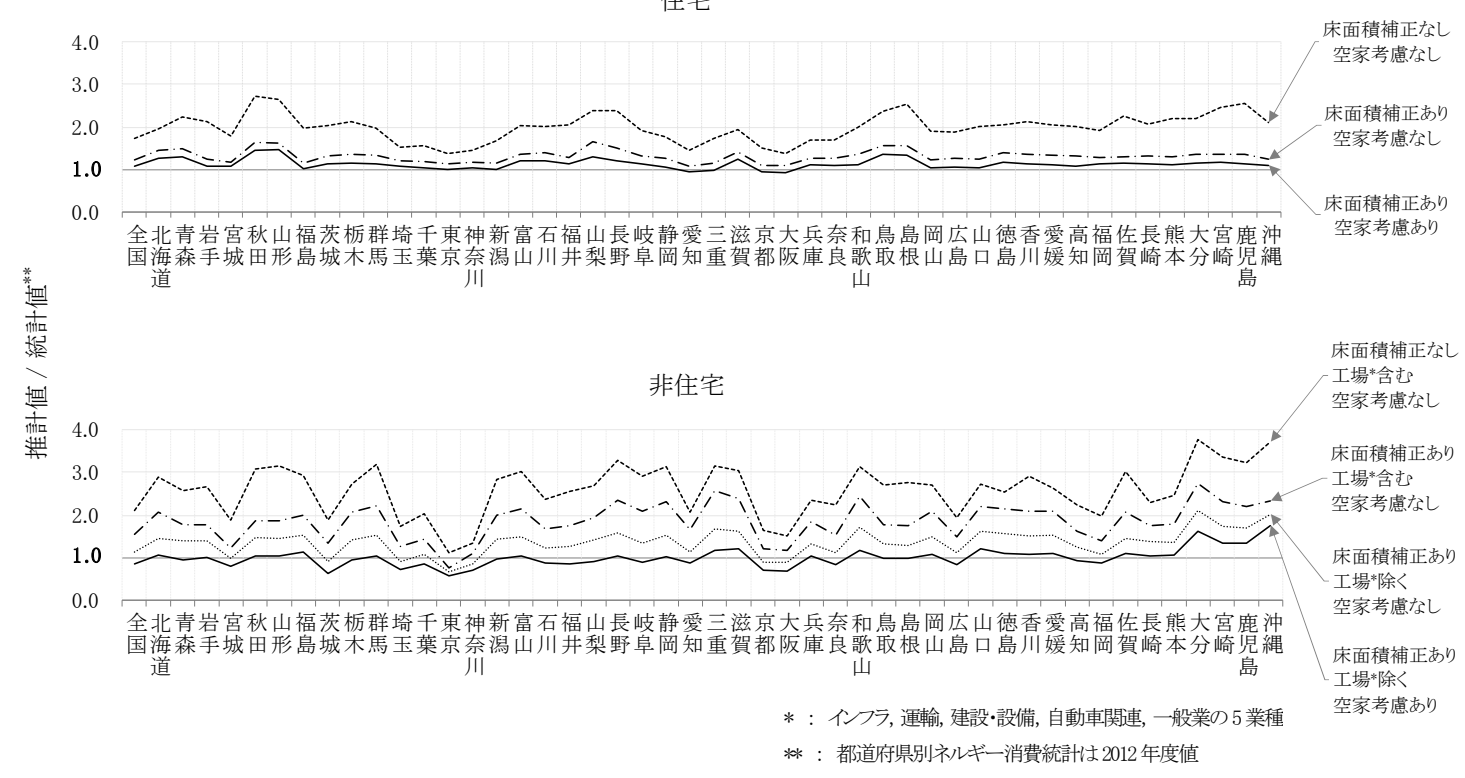

図-2 都道府県別エネルギー消費統計に対する推計值の再現性 
道府県別エネルギー消費統計は 2012 年度の值を採用し た.

住宅の総エネルギー消費量について，床面積補正な し・空家考慮なしのケースでは, 統計值に対して約 2 倍 程度の過大推計となるが，床面積補正あり・空家考慮あ りのケースではいずれも統計值との乘離が小さくなり， 再現性が大きく向上している. 住宅については床面積補 正の効果が大きいことが分かった.

補正後のケースでも青森・秋田・山形の北東北や鳥 取・島根が統計值に対して若干過大気味になっているが, これは同じ地域区分に原単位が大きい県が含まれる影響 や集合住宅の床面積が過大推計である影響によるものと 考えられる. 住宅の電力消費についてはいずれの都道府 県もさらに統計值との整合が高くなっており, 精度よく 再現されていることを確認した.

非住宅の総エネルギー消費について, 補正なしのケー スでは統計值に対して4倍近く過大に推計される都道府 県がみられるものの，床面積補正，工場の除外，空家考 慮といった補正を通じて, 概ね 1 前後のカバー率まで再 現性が向上している.これらの過大推計となる都道府県 は工場床面積が大きいことが影響として考えられる.工 場数の面では東京・愛知・大阪が多いものの, 工場 1 件 あたりの床面積は小さい事が考えられる. 非住宅につい ては床面積補正，工場の除外，空家考慮が同程度の効果 を持つことが分かった.

また，都道府県別あるいは市別の床面積補正係数およ び空家率と 10 地域別のエネルギー消費原単位を用いて, 政令市の住宅エネルギー消費量を求め, 市町村統計書の 值との比較を行った. なお, 非住宅については, 政令市 別に産業部門と業務部門を区分した統計值が得られなか ったため, 住宅についてのみ比較した. その結果, 図-3 に示すとおり，統計值に市外を含む場合を除くと，統計 に近い值を求めることができることが分かった．比較的 差が大きい京都市，大阪市，堺市は，中部地方と近畿地 方を平均したエネルギー消費原単位を用いている影響が 考えられる. なお, 床面積補正係数と空家率に市の值を 用いた場合と県の值を用いた場合との差が大きくないこ とも分かった．政令市を有する都道府県では，県と政令 市の間で床面積等の差分を取ることで，政令市を除く県

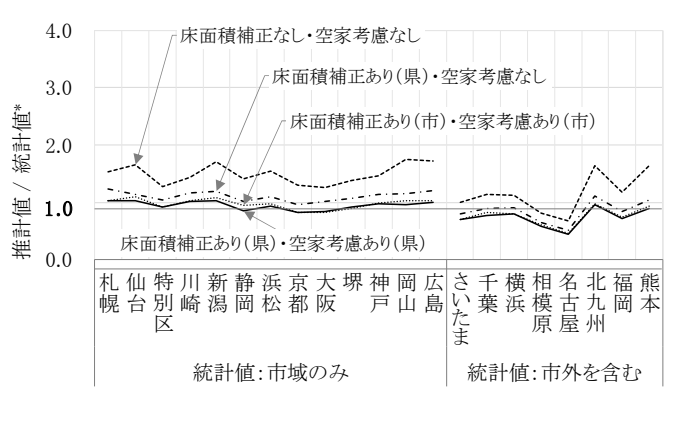

$*:$ 統計值は2012 年度の值

図-3 各市統計書の電灯消費量に対する推計值の再現性

内その他区域の床面積補正係数と空家率を求めることが できる.しかし，県と政令市の補正係数等を用いた推計 值が同等である場合には，政令市を除く県内その他区域 の補正係数等も同様の值をとることとなるため, 政令市 以外の区域の電灯消費量について県あるいは政令市の補 正係数等を用いた推計值を採用することも可能と考えら れる. また, 統計值に市外を含む市については, 本推計 手法を用いて市内の床面積を反映させた推計を行うこと で，市外分を除いたエネルギー消費量の值を求めること ができる可能性がある.

\section{4. 市区町村への適用}

ここまで推計值と比較可能な既存統計が把握できる都 道府県あるいは政令市での検証を行った。市の単位では, エネルギー消費量の統計值を用いた検証を行えるところ は少ないが，上記の方法を用いることで，一定の精度を 有する推計を行うことができる可能性がある. そこで, 策定マニュアル簡易版19による市区町村単位の $\mathrm{CO}_{2}$ 排出 量および建物ポイントデータを用いた既存手法に対し， 本手法による推計值を比較する.

千葉県市原市を対象に策定マニュアルの簡易推計によ る推計值と本研究の手法による推計值を比較した．市原 市は，工場を比較的多く含む市であり，策定マニュアル の按分法での推計を行っていることから，産業部門にも 関連しうる工場の床面積を除外する検討を行う観点から

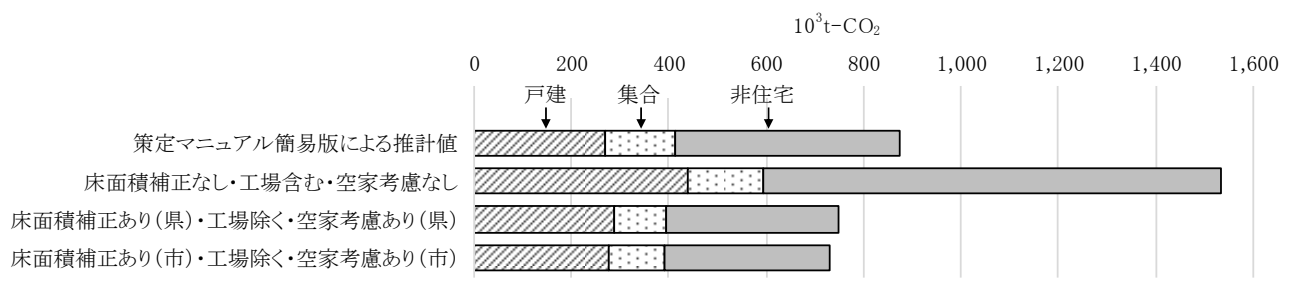

図-4 ケース別のエネルギー消費量推計結果の比較（市原市） 


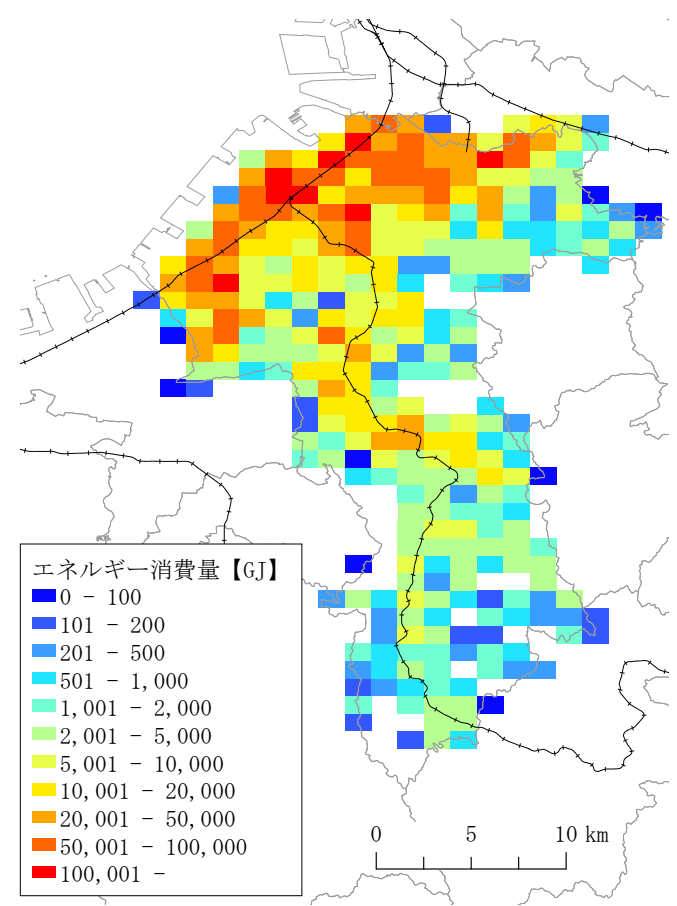

図-5 $1 \mathrm{~km}$ メッシュ別のエネルギー消費分布 : 市原市

選定した．結果を図-4に示寸通り，既存の補正無しの手 法と比較して, 半分程度の值となった。 これは, 都道府 県等での検証と同様の傾向であり，床面積や空家率の補 正を行うことにより，比較的，妥当性が高い值を求める ことができていると考えられる.

策定マニュアルの推計值とは近い值を示した. 本推計 では，住宅10地域，非住宅は5地域の原単位を用いてお り，策定マニュアルは都道府県別の原単位を用いている 等, 推計方法は異なるにも関わらず, 結果として近い值 となっている. 非住宅については, 策定マニュアルでは, 都道府県別に業務部門の従業者数あたりの排出量を用い て推計しているのに対して, 本推計では5地域別6用途別 の原単位に床面積を乗じて推計しており，本推計の方が 市における用途別床面積の割合といった特性をより詳し く反映している可能性がある.

県の補正係数を用いた推計と市の補正係数を用いた推 計では，大きな差はみられなかった。 内訳は若干異なっ ており, 千葉県の平均に対する市原市の用途の構成や床 面積を反映している点で市の補正係数を用いる方が適切 な可能性がある. ただし, 市のレベルで比較検証できる エネルギー消費量データが無いため, 推計手法間の妥当 性の判定をここで明確に行うことはできない.

本研究による床面積補正を踏まえて, 既存のエネルギ 一統計と整合の図られた，市域内の詳細なエネルギー消 費分布を把握することが可能になると考えられる. たと

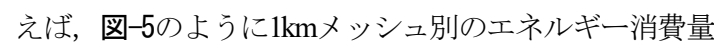

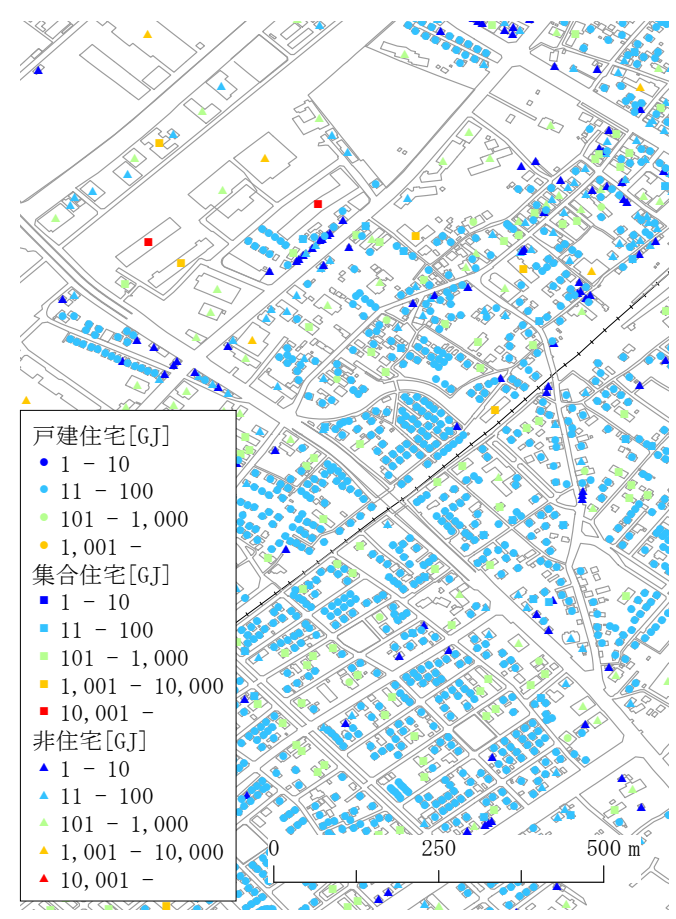

図-6 建物別のエネルギー消費分布 : 市原市五井周辺

をみることで，鉄道沿いあるいは幹線道路沿いの業務地 域, 市役所周辺の市街地，住宅団地を中心にエネルギー 消費量が高い地域が分布していることが分かる．家庭部 門と業務部門のエネルギー消費量の分布を, 統計值と整 合した值として把握できることで, 地区単位でのエネル ギー消費量を把握できるとともに，用途別の対策を導入 した際の削減可能量の見積に役立てることができる.ま た，図-6のように，地区・街区の中でのエネルギー消費 量の分布を確率的に空家を考慮した形で建物単位で知る ことができる. 街区単位でのエネルギ一消費量を把握で きるとともに, 再生可能エネルギ一や余熱を街区内で活 用できる可能性を踏まえて, 街区の更新・整備と一体と なったエネルギー施策を含む対策・政策の検討と削減効 果の把握に役立つことが期待される.

\section{5. おわりに}

本研究は建物ポイントデータの床面積補正係数を算 出・提供し, 補正した床面積データを用いて建物ポイン 卜別のエネルギー消費量の推計を試行した，床面積補正 係数は, 都道府県別の統計值に整合するように設定した。 これを用いて求めたエネルギー消費量について, 都道府 県と政令市の統計值との比較検証を行い, 既存手法より も再現性が高いことを確認した. さらに，市別の住宅建 て方別床面積補正係数を試算し, 市別のエネルギー消費 
量を求め, 策定マニュアルによる簡易推計值等と比較し た. 消費量分布を知ることもできるため, 今後, 地区・ 街区のエネルギー需給マッチングの評価を行うことで, 実行計画の策定支援に役立てることも期待できる.

集合住宅および非住宅における室単位の空室化メカニ ズムの検討と, 非住宅建物の空室率についての精査を今 後行う予定である.

謝辞 : 本研究は環境省の環境研究総合推進費 (2-1404) およびJST/RISTEX持続可能な多世代共創社会のデザイン 「多世代参加型ストックマネジメント手法の普及を通じ た地方自治体での持続可能性の確保」により実施された.

\section{参考文献}

1) 環境省 : 地球温暖化対策に係る中長期ロードマップの 提案, https://www.env.go.jp/earth/ondanka/mlt_roadmap/s hian_100331/main.pdf, 2016.03.18 最終閲覧.

2) 環境省 : 地方公共団体における地球温暖化対策の計画 的な推進のための手引き, http://www.env.go.jp/earth/ond anka/tebiki_1402/index.html, 2016.03.18 最終閲覧.

3) 国土交通省 : 低炭素まちづくり実践ハンドブック, htt p://www.mlit.go.jp/common/001023244.pdf, 2016.03.18 最 終閲覧.

4) 建築研究所 : 地方公共団体の都市計画・まちづくり分 野での地理空間データの整備・活用状況に関する調查

（2015 年 2 月実施）, http://www.kenken.go.jp/japanese/r esearch/hou/gis/gis2015tr_qr_v1.pdf, 2016.03.18 最終閲覧.

5) ゼンリン: 建物ポイントデータ, http://www.zenrin.co.jp /product/pdf/catalogue/marketing-06.pdf, 2016.03.18 最終 閲覽.

6) 川除隆広 : リノベーションされる都市のエネルギー消 費量を可視化する, 空気調和・衛生工学会学術講演会 講演論文, http://www.kinki-shasej.org/upload/pdf/3152.pd f, 2016.03.18 最終閲覧.
7) 阪田知彦, 吉川徹 : 東京都 GIS 建物ポリゴンから推定 した事業所系延床面積の補正について, GIS-理論と応 用, Vol.10, No.1, pp.85-94, 2002.

8) 総務省: 平成 26 年度固定資産価格等概要調書, 都道府 県別表 II.家屋, http://www.soumu.go.jp/main_sosiki/jichi_ zeisei/czaisei/czaisei_seido/ichiran08_h26_00.html,2014.06, 2016.03.18 最終閲覧.

9) 総務省: 平成 25 年度公共施設状況調, http://www.soum u.go.jp/iken/shisetsu/, 2016.03.18 最終閲覧.

10) 財務省 : 平成 25 年度国有財産一件別情報, http://www. kokuyuzaisan-info.mof.go.jp/kokuyu/, 2016.03.18 最終閲 覧.

11) 資源エネルギー庁 : 平成 24 年度エネルギー消費状況 調査（民生部門エネルギー消費実態調査），http://www meti.go.jp/meti_lib/report/2013fy/E003078.pdf, 2016.03.18 最終閲覧.

12) 一般社団法人日本サステナブル建築協会 : 非住宅建築 物の環境関連データベース, http://www.jsbc.or.jp/decc_d ownload/, 2016.03.18 最終閲覧.

13) 高口洋人・他 : 非住宅(民生業務部門)建築物の環境関 連データベース（DECC）の構築と解析 その 1 基 礎データベースの構築, 日本建築学会環境系論文集, Vo 1. 77, No. 678, pp. 699-705, 2012.

14) みずほ情報総研 : 低所得高齢者向け住まいの整備につ いて, http://www.mizuho-ir.co.jp/publication/report/2012/p df/mhir04_home.pdf, 2016.03.18 最終閲覧.

15) 資源エネルギー庁: 平成 24 年度都道府県別エネルギ 一消費統計調查, http://www.enecho.meti.go.jp/statistics/e nergy_consumption/ec002/, 2016.03.18 最終閲覧.

16) 環境省：地球温暖化対策地方公共団体実行計画（区域 施策編）策定マニュアル（第 1 版）簡易版, http://ww w.env.go.jp/earth/ondanka/sakutei_manual/manual_kani100 8/full.pdf, 2016.03.18 最終閲覧.

(2016. 3. 22 受付)

\title{
ESTIMATING CONSUMER SECTOR ENERGY CONSUMPTION THROUGH TOTAL FLOOR SPACE CORRECTION OF BUILDING POINT DATA
}

\author{
Masahiro ISHIKAWA, Keisuke MATSUHASHI, and Toshinori ARIGA
}

To promote global warming countermeasures in Japan, it is necessary to design an evaluation technique for the energy policy on block unit scale. Building point data has the potential to fulfill this requirement. However, building point data must be used correctly because it tends to exaggerate the estimate of the total floor area. This study aims to estimate the energy consumption of the consumer sector using the bottom-up approach through total floor space correction and vacancy rates consideration on building point data. The results of the study, estimates of the energy consumption of the prefectures, and ordinancedesignated cities confirmed that a high reproducibility compared with the statistics can be obtained. In addition, we consider the applicability of this technique in the municipalities and propose it as supporting material for the action plans for global warming countermeasures of local governments. 